\title{
New species and new records of Astrosphaeriellaceae from Andaman Islands, India
}

\author{
M. Niranjan and V.V. Sarma* \\ Department of Biotechnology, Pondicherry University, Kalapet, Pondicherry-605014, India. \\ *Corresponding authorEmail: sarmavv@yahoo.com \\ (Submitted on January 19, 2020; Accepted on April 16, 2020)
}

\begin{abstract}
Andaman and Nicobar Islands of India are relatively underexplored for fungal diversity. From the studies conducted from Andaman region, a few new species and new records have been documented. Astrosphaeriellaceae is characterized by superficial ascomata, or beneath the host periderm, thick carbonaceous walls with central ostioles, brown fusiform ascospores, hyphomycetous or ceolomycetous anarmophs. In the present paper, we introduce two new species, viz. Astrosphaeriella uniseptata and Pithomyces hyalosporae and report two new records i.e Astrosphaeriella stellata and Astrosphaeriella tornata.
\end{abstract}

Key words: Astrosphaeriellaceae, Pleosporales, Dothideomycetes, new records, new species.

\section{INTRODUCTION}

Astrosphaeriellaceae belongs to the order Pleosporales (Dothidiomycetes) and contains 5 genera (Zhang et al. 2012; Wijayawardene et al., 2018), namely Astrosphaeriella Syd. \& P. Syd., Astrosphaeriellopsis Phook. et al., Javaria Boise, Pithomyces Berk. \& Broome and Pteridiospora Penz. \& Sacc. Astrosphaeriellaceae has been established by Phookamsak \& K.D. Hyde (Phookamsak et al., 2015). Astrosphaeriella is a type genus of Astrosphaeriellaceae, and it consists of more than 50 species as mentioned in Index Fungorum, 2019. However, Wijayawardene et al. (2017a) accepted only 10 species. Other genera such as Astrosphaeriellopsis, Javaria and Pteridiospora contain two species each, while Pithomyces has 30 species. Astrosphaeriellaceae has morphological similarities and sister relation in phylogeny with Aigialaceae. The species belonging to Astrosphaeriella were mostly found on bamboo, palms and stout grasses and are distributed in subtropical or temperate regions (Zhou et al., 2003 and Phookamsak et al., 2015). Astrosphaeriella species are reported as saprobic or parasitic from diverse environments such as aquatic, submerged or terrestrial habitats, and some of the dead parts of dicotyledons (Phookamsak et al., 2015). A key was proposed for the Astrosphaeriellaceae by Phookamsak et al. (2015). Astrosphaeriella consists of yellowish brown to reddish brown ascospores, while hyaline to brown ascospores characterize Pteridiospora. Recently, Wanasinghe et al. (2018) proposed a key to species of Astrosphaeriellaceae. The genus Javaria was introduced by Boise (1984) and it is similar to Astrosphaeriella (Hyde and Fröhlich, 1998). The taxa belonging to this genus contain hyaline ascospores that are surrounded by mucilaginous sheaths and it is considered as a synonym of Astrosphaeriella.

To begin with the genus Astrosphaeriellopsis Phookamsak, J.K. Liu \& K.D. Hyde, was placed in order Pleosporales, family Incertae sedis (Phookamsak et al., 2015). Later it was transferred to family Astrosphaeriellaceae. The genus Astrosphaeriellopsis is characterized by immersed ascomata beneath the host epidermis, cylindric-clavate asci with apical rounded ends containing an apical chamber; ascospores hyaline to pale brown, 1-septate, surrounded by a mucilaginous sheath. Although Barr $(1987,1990)$ placed the genus Javaria with $J$. samuelsii as the type species in
Platystomaceae, however, it was later transferred to Melanommataceae by Tian et al. (2015). Recently Astrosphaeriellopsis has been transferred to Astrosphaeriellaceae by Wijayawardene et al. (2017a; 2018). Boise (1984) described this genus as having erumpent ascomata, conical, carbonaceous peridium, lageniform to cylindrical asci and ellipsoid to fusoid hyaline ascospores.

Astrosphaeriellaceae members are characterized by superficial ascomata; ascostromata solitary to gregarious, erumpent to superficial, carbonaceous; Peridium poorly developed at the base, asci bitunicate, fissitunicate, cylindrical to cylindric-clavate, with an ocular chamber, or Jsubapical ring; ascospores hyaline to pale brown, or reddish brown, with or without appendages and mucilaginous sheath and are saprobic or parasitic on bamboo, palm or stout grasses. Pseudoastrosphaeriellaceae was raised as a new family by Phookamsak et al. (2015) by transferring some species of Astrosphaeriella. Pseudoastrosphaeriella is defferent from Astrosphaeriella and Astrosphaeriellopsis in having hemispherical ascostromata, cylindrical asci, phylogenetic variations and morphological differences such as a long neck. Taxa with shorter necks in ascomata were transferred to the new genus Pseudoastrosphaeriella. Pithomyces is the largest genus in the Astrosphaeriellaceae as it consists of 30 species (Da Cunha et al., 2014; Phookamsak et al., 2015; Wanasinghe et al., 2018). It is characterized by mammiform to conical ascomata, cylindrical asci and brown multiseptate ascospores. Also it is morphologically distinct from other genera in having the hyphomycetous asexual states (Wijayawardene et al., 2017b) than coelomycetous asexual states.

\section{MATERIALAND METHODS}

Samples of dead and decomposing twigs fallen on the forest floor in the Andaman Islands, India, were collected in large polyethylene bags. They were rinsed with tap water to remove debris, dried overnight and packed in new plastic bags for shipment to the laboratory for further processing. Before performing the microscopic examination, the twigs were placed individually in plastic bread boxes, lined with sterile tissue paper, rehydrated by spraying sterile distilled water and incubated for a week to 3 months. Then, the samples were examined under a Stereo Zoom microscope (Optika SZM LED, Italy) to locate the fungal fruiting structures. Hand 
sections were cut with a razor blade and mounted on the slide in lactophenol or cotton blue + lactophenol. The slides were examined under the compound microscope (Olympus CH20i, Japan) for morphological characteristics. Nikon ECLIPSE TiU vertical microscope with DIC lenses equipped with Nikon DS - Fi2 digital camera, Japan, was used to take photomicrographs. The measurements were carried out with the Nikon NIS - Elements - Imaging Software version 4.4 program. The photo plates were prepared with the help of Microsoft Power Point and Adobe Photoshop version 7.0. The morphological identification was made by consulting the recent literature (Chen and Hsieh, 2004; Fröhlich and Hyde, 2004; Tanaka and Harada, 2005; Phookamsak et al., 2015; Wijayawardene et al., 2018; Wanasinghe et al. 2018). Herbarium specimens were deposited at the Ajrekar Mycological Herbarium (AMH), Pune and the Department of Biotechnology, University of Pondicherry.

\section{RESULTS AND DISCUSSION}

\section{Taxonomy}

\section{Astrosphaeriella stellata (Pat.) Sacc. Sylloge Fungorum} 24 (2): 938 (1928).

Figs. 1. a-e

Saprobic on unidentified Bamboo culms. Teleomorph: Ascostromata numerous, erumpent to superficial, opaque, inverted conical, carbonaceous, immersed in host epidermis, uniloculate, glabrous, brittle, ostiole central, with a small porelike opening. Peridium varying in thickness, poorly developed at the base, laterally composed of several layers of thick, dark

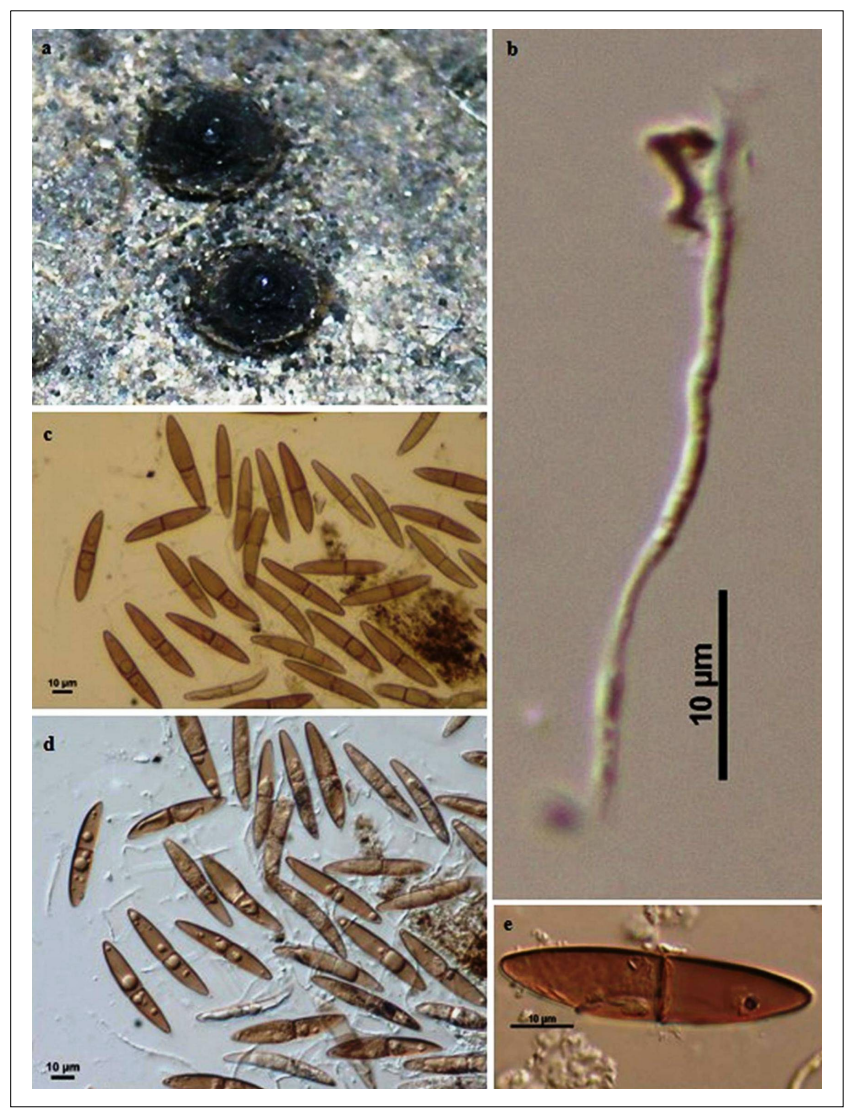

Fig.1. Astrosphaeriella stellata (PUFNI 301): a. Ascostromata; b. Pseudoparaphyses; c-e. Ascospores. opaque and melanized cells, arranged in textura angularis to textura prismatica. Hamathecium: pseudoparaphyses numerous, anastomosing, septate, branched. Ascospores 45-50 $\times$ 7.5-8.7 $\mu \mathrm{m}$, brown, 1-septate, multiguttulate, apical cells wider and longer than the basal cells, septum centrally constricted, with crescent germ slit, straight to slightly curved, smooth walled. Anamorph: Undetermined.

Material examined: INDIA, Andaman and Nicobar Islands, Middle Andaman, Nimbudera (12 43 '40'N 92 53'1.9'E). Recorded on unidentified Bamboo culms, February 3, 2016, M. Niranjan \& V.V. Sarma (PUFNI 301). Additional specimens examined: South Andaman, Port Blair, Chidiya Tapu (11 31'7" N 92 42'52"E) (T101F1) on an unidentified twig, February 7, 2016.

Remarks: Currently there are 10 species accepted in Astrosphaeriella (Wijayawardane et al., 2017a). It has inverted conical ascomata with smooth surface, different from the other genera of bambusícolous fungi. Our collection has ascospores that are of similar in size as that of the type (45$50 \times 7.5-8.7 \mu \mathrm{m}$ vs. (36-) 38-45 (-47) (-53) × 5-7 $\mu \mathrm{m})$. We were unable to locate the intact asci in the specimens that had ascomata that were fully mature and dry.

2. Astrosphaeriella tornata (Berk. \& M.A. Curtis) D. Hawksw. \& Boise, Sydowia 38: 119(1986). Figs.2.a-n

Saprobic on a Calamus andamanicus rachis. Teleomorph: Ascomata $560-825 \times 623-700 \mu \mathrm{m}$ perithecial, scattered,

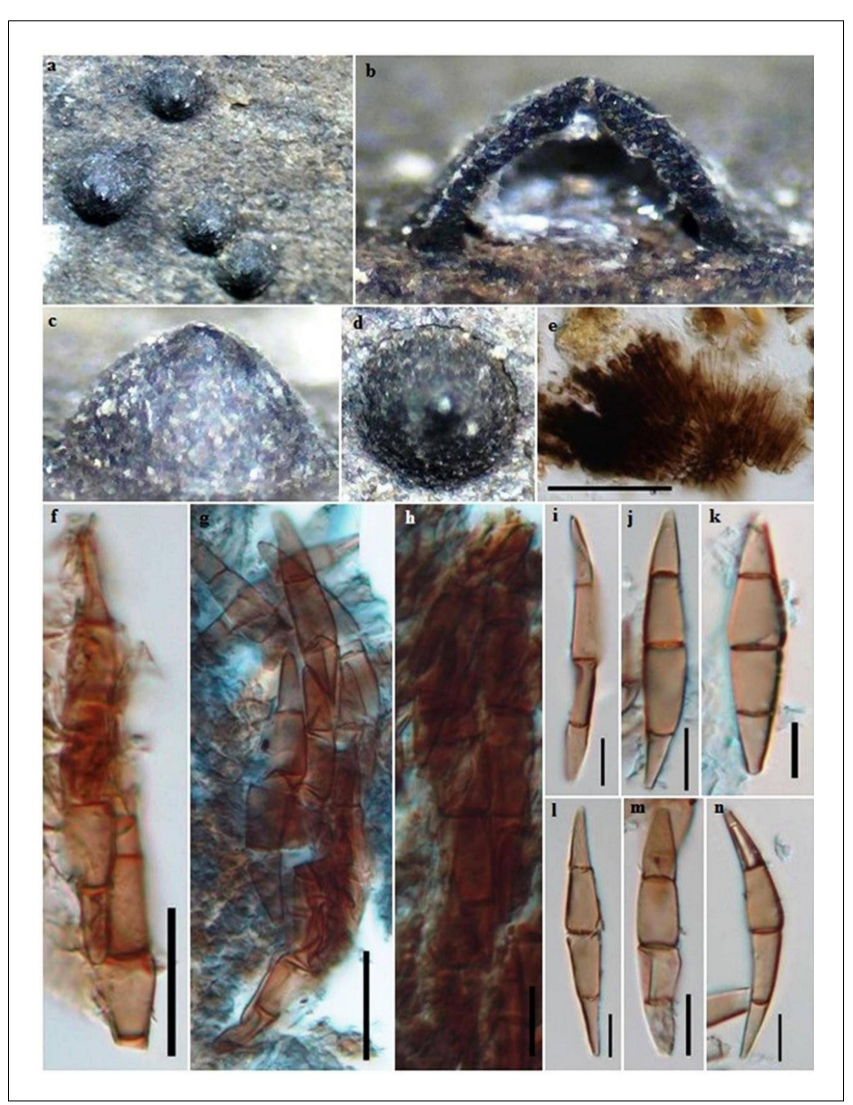

Fig.2. Astrosphaeriella tornata (PUFNI 174103): a-d. Ascostromata; e. Textura prismatica; f-h. Asci; i-n. Ascospores (Scale bars: $\mathbf{e}=50 \mu \mathrm{mf}, \mathbf{g}=20 \mu \mathrm{m} \mathbf{h}-\mathbf{0}=10 \mu \mathrm{m}$ ). 
superficial, inverted conical or pyramidal, black carbonaceous, brittle, central papillate. Asci unitunicate, cylindrical. Ascospores 37.5-55 × 4-8.7 $\mu \mathrm{m}(=45.7 \times 7.4$, $\mathrm{n}=25$ ), 8-spored, bi or tri striate, brown, fusiform, 3- septate, with strong central constrictions, polar septa slight constricted, acute apical ends, sometimes wider, straight to slightly curved, smooth walled. Anamorph: Undetermined.

Known distribution: Brazil (Vitória et al., 2016), India (In our collection), Mexico (San Martin and Lavin, 1999), Surinam (Hyde and Fröhlich, 1998) and Thailand (Phookamsaketal., 2015).

Material examined: INDIA, Andaman and Nicobar Islands, North Andaman, Diglipur, Mohanpur (13 ${ }^{\circ} 11^{\prime} 25.5^{\prime \prime} \mathrm{N}$ 92 53'23.7'E). Recorded on a Calamus andamanicus rachis, January 2, 2017, M. Niranjan \& V.V.Sarma (PUFNI 174103). Additional specimens examined: South Andaman, Mount

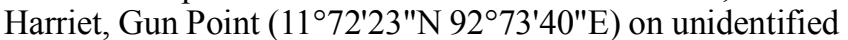
twig (T12F1), December 7, 2017); North Andaman, Diglipur, Ganadabla $\left(12^{\circ} 55^{\prime} 33^{\prime \prime} \mathrm{N} 92^{\circ} 500^{\prime} 32^{\prime \prime E}\right)$ on Calamus andamanicus (T373F1), January 6, 2017.

3. Astrosphaeriella uniseptata M. Niranjan \& V.V. Sarma sp. nov.

Figs. 3. a-o

\section{Index Fungorum Number: IF557069}

Etymology: The specific epithet uniseptata refers to the presence of single septate ascospores.

Diagnosis: The new species has hyaline, one-septate ascospores that are slightly constricted.

Saprobic on Miliusa tectona. Teleomorph: Ascomata perithecial, solitary to scattered, conical, lignicolous, black, thick, carbonaceous, unipartite. Peridium, brittle. Cells of textura prismatica that are verruculose. Hamathecium: pseudoparaphyses 1-1.5 $\mu \mathrm{m}$ in width, anastomosing, filamentous, septate, branched, loosely connected, longer than asci. Asci 175-262 × 20-30 $\mu \mathrm{m}(=220.2 \times 24.7, \mathrm{n}=19)$, bitunicate, fissitunicate, 8 - spored, overlapping uni-biseriate, cylindrical, with an ocular chamber in apical apices, short pedicellate, smooth-walled, persistent. Ascospores 52.5-60 $\times$ $7.5-10(12.5) \mu \mathrm{m}(=55.80 \times 10.1, \mathrm{n}=17)$, hyaline, verruculose, 1- septate, with a mucilaginous sheath. Anamorph: Undetermined.

Material examined: INDIA, Andaman and Nicobar Islands, North Andaman, Panihutti (13²1'24'N 92 55'57'E). Recorded on Miliusa tectona twig, February 4, 2016, M. Niranjan \& V.V. Sarma (PUFNI 439).

Remarks: Sixty six Astrosphaeriella species are documented in Index Fungorum of which 10 species are accepted in a recent article (Wijayawardane et al. 2017a). Astrosphaeriella vesuvius has superficial ascomata similar to our collection, but is distinct in having 3-5 septate ascospores that become brown at maturity. A. aosimensis is the only species considered to have 1-septate hyaline ascospores in the genus Astrospheriella (Hawksworth and Bois, 1985). Phookamsak et al. (2015) added two new species to this genus. Hyde and Fröhlich (1998) considered A. aosimensis to be a synonym of $A$. bakeriana. Liu et al. (2011) constructed a phylogeny for $A$. bakeriana which

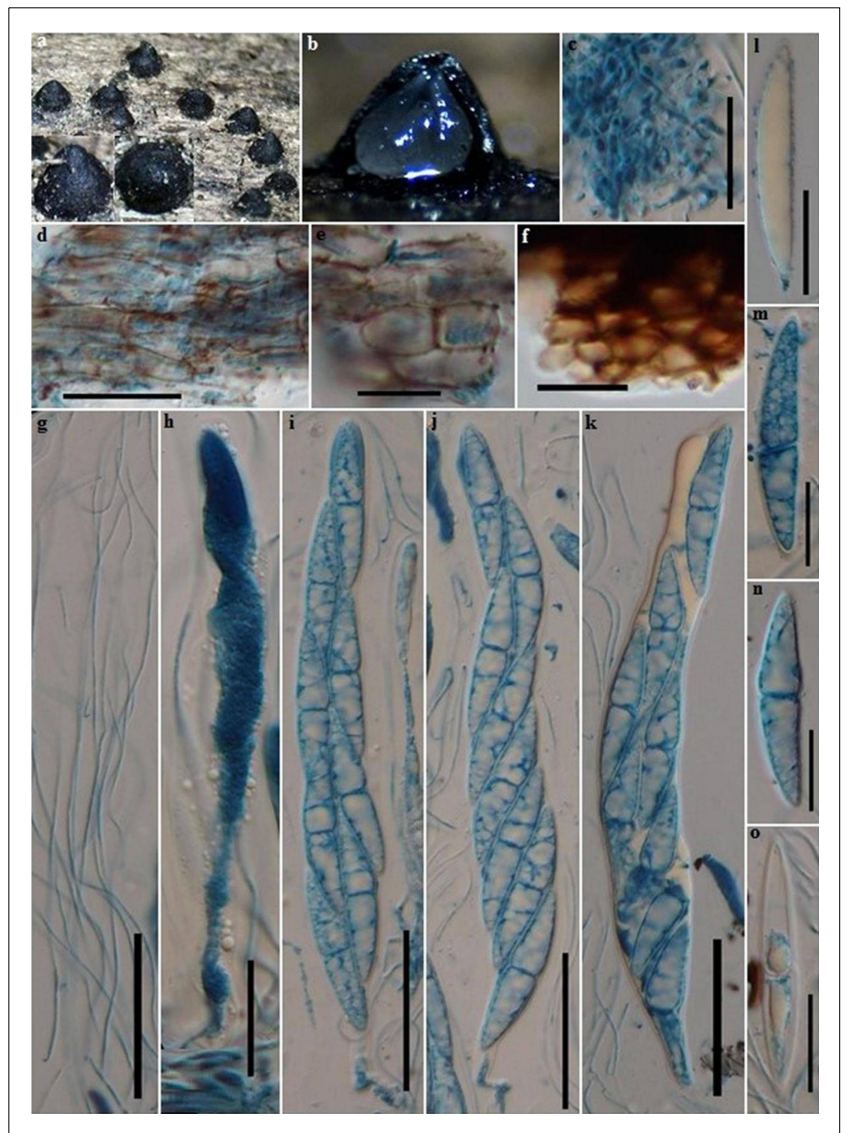

Fig.3. Astrosphaeriella uniseptata (PUFNI 439 Holotype): a. Ascomata; b. Vertical section of ascoma; c. Hamathecium; d. Textura prismatica; e-f. Textura angularis; g. Pseudoparaphyses; h-k. Asci; i-o. Ascospores (Scale bars: i-k $=50 \mu \mathrm{mc}, \mathbf{d}, \mathbf{g}, \mathbf{h}, \mathbf{l}-\mathbf{0}=20 \mu \mathrm{m}$ $\mathbf{e , f}=10 \mu \mathrm{m})$.

showed that it has a distinct clade from the known species of Astrosphaeriella. A. bakeriana has therefore been transferred to a new genus Astrosphaeriellopsis (A. bakeriana). A. bakeriana is distinct from our species in that the ascomata are erumpent and covered by host periderm and ascospores have a thick sheath. Hyde and Fröhlich (1998) included 10 new species in Astrosphaeriella and provided a pictorial key to the species. Among these A. angustispora has stromata closely related to Astrosphaeriella uniseptata. However, A. uniseptata is distinct from A. angustispora in having wider asci (175-262.5 $\times 20-30 \mu \mathrm{m}$ vs. 85-110 $\times 5-5.8$ $\mu \mathrm{m})$ and larger ascospores $(52.5-60 \times 7.5-10 \mu \mathrm{m}$ vs. $25-30 \times$ $2.3-2.8 \mu \mathrm{m})$ with constricted septa. Therefore, we introduce a new species $A$. uniseptata to be accommodated in Astrosphaeriella based on the morphological differences discussed above.

4. Pithomyces hyalosporae M. Niranjan \& V.V. Sarma
sp.nov.
Figs. 4: a-n Index Fungorum Number: IF557068

Etymology: The specific epithet hyalosporae refers to the presence of hyaline ascospores.

Diagnosis: The new species is distinct in having the 


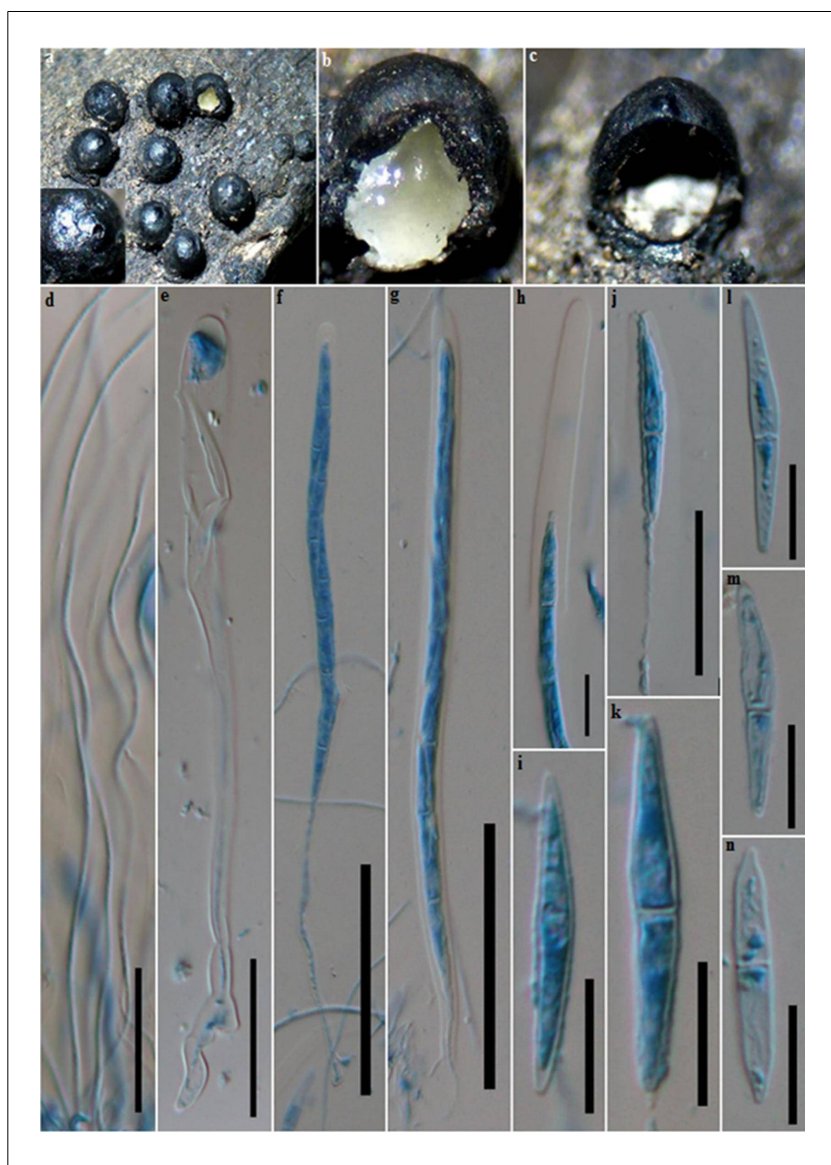

Fig. 4. Pithomyces hyalosporae (PUFNI 17456): a. Ascomata on host; b-c. Vertical section; d. Paraphyses; e-h. Asci; j. Apical ring; i, k-n. Ascospores (Scale bars: f, $\mathbf{g}=50 \mu \mathrm{m}$ $\mathbf{d}, \mathbf{e}, \mathbf{j}=20 \mu \mathrm{m} \mathbf{h}=10 \mu \mathrm{m} \mathbf{h}, \mathbf{i}, \mathbf{k n}=10 \mu \mathrm{m})$.

mammiform ascomata, cylindrical asci and hyaline fusiform ascospores.

Saprobic on unknown decaying twig. Teleomorph: Ascomata perithecial, scattered, superficial, mammiform, thick carbonaceous wall obtuse towards the apex, with central apical pore, having hyaline ascomatal contents. Peridium 45 $\mu \mathrm{m}$ thick, consists of thick carbonaceous wall and inner hyaline layer. Haimathecium: pseudoparaphyses septate, unbranched, $1.7 \mu \mathrm{m}$ wide. Asci 92-120 × 4.5-7.5 $\mu \mathrm{m}(=104.1$ $\times 5.4, \mathrm{n}=25)$, bitunicate, fissitunicate, 8-spored, long cylindrical, rounded apical ends with an ocular chamber, short pedicellate. Ascospores 22.5-27.5 × 2.5-3.5(4.5) $\mu \mathrm{m}$ (= $23.7 \times 3.1, n=25)$, hyaline, fusiform, overlapping biseriate, 1 septate, slightly constricted at the septum, acute apices, smooth walled. Anamorph: Undetermined.

Material examined: INDIA, Andaman and Nicobar Islands, South Andaman, Port Blair, Chidiya Tapu (11 29 '23'N 92 42'36”E). Recorded on unidentified twig, January 8, 2017, M. Niranjan \& V.V. Sarma (PUFNI 17456).

Remarks: Pithomyces hyalosporae is similar to genera Astrosphaeriella and Javaria (Hyde and Fröhlich 1998; Phookamsak et al., 2015) in having superficial carbonized ascomata and hyaline ascospores that are surrounded by mucilaginous sheaths. Though the present taxon fits in the genus Astrosphaeriellopsis based on the colour and septation of the ascospores, the ascomatal characters of $P$. hyalosporae, however, are distinct from Astrosphaeriellopsis in having mammiform ascomata, which bring it closer to Pithomyces species (Wanasinghe et al., 2018). Fusiform ascospores are found in Astrosphaeriella, Astrosphaeriellopsis, Javaria and Pithomyces. Superficial ascomata are commonly found in Javaria and Pithomyces. Mammiform ascomata, cylindrical asci and fusiform ascospores present in our taxon $P$. hyalosporae are common features with the genus Pithomyces. P. hyalosporae is, however, distinct from other species of this genus in having hyaline ascospores. Hence, based on the morphological differences presented above, a new species $P$. hyalosporae, is introduced in the genus Pithomyces.

\section{ACKNOWLEDGEMENTS}

The authors thank the Science and Engineering Research Board (SERB), Ministry of Science and Technology, Government of India for a financial support (SERB/SB/ SO/PS/18/2014 dt. 19.5.2015). M. Niranjan thanks SERB, MST, Govt. of India for providing the SRF scholarship. We would also like to thank the Forest Department of the Andaman and Nicobar Islands, India and the Divisional Forestry Offices of northern, middle and southern districts of Andaman for providing permission to collect research samples from their respective jurisdictions. The Biotechnology Department of the University of Pondicherry is thanked for providing the facilities.

\section{REFERENCES}

Barr, M.E. 1987. Prodromus to class Loculoascomycetes. Newell. Inc, Amherst.

Barr, M.E. 1990. Melanommatales (Loculoascomycetes). American Flora Ser. II, vol 13. New York Botanical Garden, 129 pp.

Boise, J. 1984. New and interesting fungi (Loculoascomycetes) from the Amazon. Acta Amazonica 14:49-54.

Chen, C.Y. and Hsieh, W.H. 2004. Astrosphaeriella from Taiwan, including two new species. Botanical Bulletin of Academia Sinica 45:171-178.

Da Cunha. K.C., Sutton, D.A., Gené J., Cano, J., Capilla, J., Madrid, H., Decock, C., Wiederhold, N.P. and Guarro, J. 2014. Pithomyces species (Montagnulaceae) from clinical specimens: identification and antifungal susceptibility profiles. Medical mycology 52:748-57.

Fröhlich, J. and Hyde, K.D. 1995. Astrosphaeriella fronsicola sp. nov. associated with leaf spots of Oraniopsis and other palms. Mycological Research 99: 453-456.

Hawksworth, D.L. and Boise, J.R. 1985. Some additional species of Astrosphaeriella, with a key to the members of the genus. Sydowia: Annales mycologici 38: 114-124.

Hyde, K.D .and Fröhlich J. 1998. Fungi from palms XXXVII. The genus Astrosphaeriella, including ten new species. Sydowia 50:81-132. 
Index Fungorum. 2019. Indexfungorum.org/Names/ names.asp.

Liu, J.K., Phookamsak, R., Jones, E.G., Zhang, Y., Ko-Ko, T.W., Hu, H.L., Boonmee, S., Doilom, M., Chukeatirote, E., Bahkali, A.H. and Wang Y. 2011. Astrosphaeriella is polyphyletic, with species in Fissuroma gen. nov., and Neoastrosphaeriella gen. nov. Fungal Diversity 51:135-54.

Phookamsak, R., Norphanphoun, C., Tanaka, K., Dai, D.Q., Luo, Z.L., Liu, J.K., Su, H.Y., Bhat, D.J, Bahkali A.H., Mortimer, P.E. and Xu J.C. 2015. Towards a natural classification of Astrosphaeriella-like species; introducing Astrosphaeriellaceae and Pseudoastrosphaeriellaceae fam. nov. and Astrosphaeriellopsis, gen. nov. Fungal Diversity 74:143-97.

SanMartín, F.E. and Lavín, P. 1999. Cuatroespecies y unavariedad del género Astrosphaeriella (Dothideales, Melanommataceae) de México. Acta Bot Mex 46:19-27.

Tanaka, K. and Harada, Y. 2005. Bambusicolous fungi in Japan (4): a new combination, Astrosphaeriella aggregata. Mycoscience 46:114-8.

Tian, Q., Liu, J.K., Hyde, K.D., Wanasinghe, D.N., Boonmee, S., Jayasiri, S.C., Luo, Z.L., Taylor, J.E., Phillips, A.J., Bhat, D.J. and Li, W.J. 2015. Phylogenetic relationships and morphological reappraisal of Melanommataceae (Pleosporales). Fungal Diversity 74:267-324.

Vitória N.S., Cavalacanti, M.A.de. and Bezerra, J.L. 2016. Species of Astrospheaeriella and Fussuroma from palms: new records for South America and Brazil. Nova Hedwigia 102: 129-140.

Wanasinghe, D.N., Jeewon, R., Jones, E.G., Boonmee, S., Kaewchai, S., Manawasinghe, I.S., Lumyong, S. and Hyde, K.D. 2018. Novel palmicolous taxa within Pleosporales: multigene phylogeny and taxonomic circumscription. Mycological progress 7:571-90.

Wijayawardene, N.N., Hyde, K.D., Lumbsch, H.T., Liu, J.K., Maharachchikumbura, S.S., Ekanayaka, A.H., Tian, Q. and Phookamsak, R. 2018. Outline of ascomycota: 2018. Fungal Diversity 8:167-263.

Wijayawardene, N.N., Hyde, K.D., Rajeshkumar, K.C., Hawksworth, D.L., Madrid, H., Kirk, P.M., Braun, U., Singh, R.V., Crous, P.W., Kukwa, M. and Luecking, R. 2017a. Notes for genera: Ascomycota. Fungal Diversity 6:1-594.

Wijayawardene, N.N., Hyde, K.D., Tibpromma, S., Wanasinghe, D.N., Thambugala, K.M., Tian, Q., Wang, Y. and Fu, L. 2017b. Towards incorporating asexual fungi in a natural classification: checklist and notes 2012-2016. Mycosphere 8:1457-555.

Zhang, Y., Crous, P.W., Schoch, C.L. and Hyde, K.D. 2012. Pleosporales. Fungal Diversity 53:1-221.

Zhou, D., Cai, L. and Hyde, K.D.2003. Astrosphaeriella and Roussoella species on bamboo from Hong Kong and Yunnan, China, including a new species of Roussoella. Cryptogamie Mycologie. 4: 191-197. 